\title{
JOURNALISM IN THE INFORMATION AGE: A GIFT OR A CURSE: A CASE STUDY OF FREEDOM OF THE PRESS IN INDONESIA
}

\author{
Haryanto \\ Mass Communication Department, the Faculty of Social and Political Sciences, The University of Sebelas \\ Maret Solo, Central Java, Indonesia
}

\begin{abstract}
There is no doubt that Mass Media (journalism) have great impact on social life. The impact could be negative or positive. In the hand of good people mass media can be used to mobilize people toward constructive activities. In the contrary, in the hand of bad people, it can encourage destructive social movement.
\end{abstract}

The application of information technology and communication can amplify both negative and positive social impact of mass media (journalism). This reality challenges the author to do analysis to weight the positive impact of mass media (journalism) against its negative impact in relation to freedom of the press implementation in Indonesia.

A content analysis of private television news program was conducted to collect empirical evidences. Two issues were chosen as the sample of the study i.e the case of Freeport gratification and the dispute between Basuki Tjahaya Purnama (Governor of Jakarta) and Haji Lulung (the chair of Jakarta Municipality Parliament). These disputes were considerably big issues nationally and got greater attention among Indonesia television stations. The dispute was also broadcasted in several days, colorizing most of news program in any kinds of broadcasting forms.

Two private television stations (TVOne and Metro TV) are chosen as the sample of media. They are really blowing up the issues. The dispute colorizes Television news program in almost 7 days a week, either in the form of hard news and/or any other form of news programs i.e. dialog, debate etc. About 135 news items related to the dispute are identified.

The research reveals that the media successfully provoked public to get involved in the dispute. Through framing strategy the media are able to influence public opinion. Moreover, the media are able to stream the public's judgment toward who is right or wrong, who is guilty or innocence. The impact is amplified by the use of social media leading to the emergence of public protest.

The author comes to a big conclusion that through its broadcasting, Indonesia televisions contribute the raise of political chaos lately. In the process of democratization, especially in developing countries, media (freedom of the press) could be a gift if the media are managed wisely. But, in the same time, media might take a destructive role.

Keyword: Media studies, media impact, Indonesia private television program, journalism ethics, freedom of the press, framing, content analysis

\section{INTRODUCTION}

\section{Background}

Each country has different history concerning with its mass media (journalism) according to political system applied in the respective country. Studying the role of media/journalism within a country/society, therefore, should take account the social and political system

Corresponding Author: bmw.bmaryanto@yahoo.com 
implemented in the country.

Indonesia has a unique story about journalism history. "Hate journalism" might be the main character of Indonesian journalism from time to time. This character is indicated in the history of Indonesian press from colonialism to reformation era, though the character is expressed in the different form.

It is believed this character will affect the way journalist frames and reports news. "Hate manner" will create prejudice leading to questioning the journalist's objectivity, balancing and accuracy in writing report. This is the reason why the author uses the word "curse" against "gift" in the title. The author believes that the word "curse" has very strong negative meaning. Since, the author has difficulty to find the proper word to express what is going on. It is just to attract an attention that the application of freedom of the press in Indonesia at present has developed toward beyond expected (colorized by hate journalism).

Having actual freedom of the press since reformation movement (1978), Indonesia faces a serious problem concerning with developing an improving the quality of democracy. The government has difficulty to rule more than 200 million people and more than 30 new political parties. Whilst they are expected to play a political enlighten role for the development of democracy, the media tend to use the situation as news commodity. This atmosphere is becoming worse because some of the media tend to frame news containing "hate manner", encouraging political chaos.

Historically, the development of freedom of the press can be divided into four eras i.e. colonialism era, Soekarno era, Soeharto era, and reformation era. Each era shows different characteristic according to the social and political situation in the respected time.

\section{Colonialism Era (before 1945)}

Through his critic to "politik etis" (ethics policy) introduced by colonial government, Eduard Douwes Dekker (1879 - 1950) has inspired local political elites to use mass media (newspaper) to improve Indonesian education in order to get independency from colonial government. He has successfully provoke -through his critical writing-- Indonesian political elite nationalism and change the way of struggling for independency (Wikipedia).
Mr Dekker is the person who help to support the bear of Boedi Oetomo, the first society (mass) organization which struggle for independence through modern organization. Since that more new society organization emerge causing problem for the colonial government. $\mathrm{He}$ is also the person who inspires to Indonesian political elites to use mass media to build nationalism among Indonesian people.

In the perspective colonial government, Dekker is claimed as a person who develops "hate journalism". Through his critical writing, he has successfully encourages the indigenous people to do protest openly causing him got exile. His writing attracts also more journalists and local political actors to learn how to write propaganda to build stronger nationalism (See Arifin, 1990; Suwirta, 1999).

In short, Dr. Eduard Douwes Dekker is one of the great journalist born and lived in Indonesia who is successful in inspiring Indonesian journalists to provoke people movement in getting independency.

On the basis of the above description, it can be stated that "hate journalism" (propaganda) is the main characteristic of the Indonesian media. Another interesting character is that the media is belong to political leader (See Arifin, 1990; Suwirta, 1999). This is not surprising since most of the political leaders are businessman or local bureaucracy officer (kaum priyayi).

After defeated by Japanese in the Second World War, Dutchman are leaving Indonesia, and Japanese governs Indonesia for 3 and a half years. In this period, the existing newspapers and other media are taken over by the Japanese.

For some reason, Indonesian journalists get advantage from Japanese occupation. Newspapers are not allowed to use of Dutch language. This policy provides the opportunity of promoting Indonesian as a national language. Japanese is also teaching Indonesian journalists about how to write effective propaganda systematically, how to manipulate data for propaganda purposes etc. (Suwirta, 1993). The idea is using Indonesian journalists to weaken enemy courage through propaganda.

\section{Sorkarno era $(1945$ - 1965)}

This era is characterized by multi party political system. Each party publishes its own newspaper as a vehicle to advertise its political program, to mobilize 
its members/ participants, and to get support from public. Independent newspapers should have affiliation to particular political party (see Arifin, 1990). The main role of mass media (newspapers) is as a political instrument. Journalists are free to criticized government policy and or other political party policy/program. Since the journalist are more experienced in writing propaganda -as described before - they tend to produce "hate journalism", and sometimes encourage horizontal conflict among political member coming from different party. The conflict quite often provoke political chaos causing social, economy, and political instability.

By years, the situation is getting worst and uncontrollable. Therefore, Soekarno announces government regulation (1960) to rule the implementation of freedom of the press in Indonesia. Since that, the government take control to the press. Newspapers should support government programs, create social harmony across political party members/constituent, and establish social, economy and political stability. This situation does not take long time since Soekarno has to step down as the President of Indonesia in 1966.

\section{Soeharto era}

At the beginning of Soeharto era, Indonesia applies multiparty political system and each political party publishes its own newspapers or bulletin as its political campaign tool. Propaganda dominates the manner of journalism at the time. The propaganda encourage political chaos and horizontal conflict leading to political instability.

In order to build political stability, Sorharto merges more than 10 political parties into 3 big parties according to party's ideology similarity ie. Golkar, Partai Persatuan Pembangunan and Partai Demikrasi Indonesia. Moreover, Soeharto does not allowed political parties to publish their own media /newspapers. Mass media should be published and managed independently.

Having experience from Soekarno era, Mr. Soeharto takes fully control mass media operation. Journalists are not allowed to do critic against government policy. Even though freedom of the press is guaranteed by law, in fact, criticizing government policy can bring journalist in prison.
Mr Soeharto does really understand the role and the function of mass media to mobilize public to get involved in the national development process. What Mr. Sorharto concern is how to push economic growth as soon as possible to release Indonesia from economic crisis. Mass media should develop social responsibility instead of pursuing freedom of speech. Media have an honor duty to improve quality of Indonesian live.

Through Department of Information (Departemen Penerangan) Mr. Soeharto develops his own concept and strategy about journalism that is called development journalism. The media and journalist should converge their strength and effort to accelerate economic development.

This is Soeharto's strategy to control freedom of the press in Indonesia. Freedom of the press is guaranteed by the law. Media or journalists are free to express their ideas and write a critic. But the idea should complement or support the government policy, and the critic is not allowed against the government decision. It likes releasing a snake but the nail is hold tightly.

For thirty years $\mathrm{Mr}$ Soeharto does successfully control the media and create a conducive political stability that is suitable for economic development.

\section{Reformation era}

National political protest wave in 1978 has forced Mr. Soeharto to step down from his position as the second President of Indonesia. The step down of Mr. Soeharto gives second win to Indonesian journalists to gauge freedom of the press, which was bounded strictly by government regulation during Sorharto's era. In response to this situation BJ Habibie, acted as the third President of Indonesia, announce new regulation to facilitate the implementation of freedom of the press in Indonesia. Government permission is no longer needed to publish newspapers, to build television or radio broadcasting

Since that the number of mass media (printed and electronic) grows significantly. Each media compete to each other in order to keep operate. The competition challenges media management and journalists to find a way of winning public attention and support. Taking benefit from the situation, media/journalists use freedom of the press as their justification to frame issue in such a way just to 
increase news value. They use freedom of the press as a vehicle just to meet their demands. Honesty, fairness and social responsibility are no longer being guidance for conducting freedom of the press.

This situation is getting worse by times. Anom (2011) describes 4 (four) biases dealing with journalism practices in Indonesia in the reformation era, as follows:

1. Bombastic title/headline.

Media/journalist tends to use bombastic words that quite often do not represent its content. The title/headline sometime does not match with the content. This is one of media/journalists strategy to raise news value in order to attract public attention.

2. The use of "as said" as news source. Media/journalist are accustomed with the use of "as said", as publicly knows", and "according to source who are not willing to be mentioned". This is not commensurate with the principle of objectivity in which journalist should mention the clarity of news/information source.

3. Elite's opinion is claimed as public opinion. Media/journalists facilitate some controversial political elite to speak on behalf of public interest. Even though the speech do not represent the public interest. It is just the politician's claimed.

4. Information/news is presented partially. Instead of comprehensive presentation, media/journalist tends to frame issue or event in such a way to attract public curiosity. This is not wrong. However, considering the level of Indonesian educational which is considered relative low, this strategy is not so wise. Most of Indonesian people have still difficulties to select and understand information critically and objectively. They are easily influenced by rumors and gossips.

As the media/journalist get used to the four biases, and on the basis of freedom of expression, they go further in wrong direction. The past Indonesian journalist manner is, as a propagandist and tends to develop "hate journalism", pulled out and colorize journalism practices in this era.

This situation is getting worse and challenge the author to conduct a study to weight the advantages against the disadvantages of freedom of the press practices in Indonesia.

\section{Focus of the study}

It is believed that mass media/journalism has great impact on social and political changes. Its impact could be positive or negative. Media is a neutral vehicle. Its value depends very much on who use it, to what purpose, and how it is used. In the hand of good journalist, mass media can be used to improve quality of life, in the contrary, mass media can encourage social distrust, provoking political chaos.

Thomas Jefferson, the famous American President, for example, is one of person who admires to mass media by saying "if it left to me to decide whether we should have a government without newspapers or newspapers without a government, I should not hesitate a moment to prefer the latter" (Thomas Jefferson to Edward Carrington, 1787. ME 6:57). This quotation is showing Jefferson's respect to journalism.

Napoleon Bonaparte, France influential leader, has different opinion about journalism. He said

" a journalist is a grumbler, a censurer, a giver of advice, a regent of sovereigns, a tutor of nations. Four hostile newspapers are more to be feared than a thousand bayonets". (http://www.azquotes.com/quote/1143 536).

The two citation shows two different sides of media. And, the media can play both sides interchangeably. Freedom of the press is needed to facilitate mass media in order to be able to play its role and function properly. However, it will be very dangerous if the execution of the freedom of the press is out of control. As stated by Theodore Roosevelt (The man in the arena):

"The power of journalist is great, but he entitled neither to respect nor admiration because of that power unless it used aright. He can do, and often does, great good. He can do, and often does, great mischief... Offenses against taste and morals, which are bad enough in private 
citizen are infinitely worse if made into instrument for debauching the community through a newspaper

(Connect!ons: med! aLit oment: 2016)

As implied in the above title, the emphasis of this study is on freedom of the press practices, especially the comparison between advantages and disadvantages of freedom of the press practices in Indonesia. This research is not to judge the value or the role of freedom of the press in a democratic country. But, it is more likely to weight the benefit against the detriment of journalism practices in Indonesia.

The focus of the study, then, is operationalized in the following research question:

- How do journalists treat freedom of the press?

- How far journalist implement the principles of freedom of the press?

- Is the benefit out of the detriment or in the contrary?

\section{METHODOLOGY}

To answer those questions, two issues, broadcasted by TvOne and Metro TV (the media sample), are selected as the unit analysis. Those issues are the dispute about Mr. Setyo Novanto (the Head of Indonesian Parliament) and Mr. Basuki Tjahaja Purnama (the Governor of Jakarta). These issues are considered as the most popular national issues at the time.

News broadcasted by the media sample are recorded, and then analyzed by means of content analysis and framing techniques. Content analysis is used to identify and determine its objectivity, balance, neutrality and so on. This kind of data will be used to answer the first and the second research question.

Framing technique is used to collect data or information about "intended purposes" embedded in the news. This data is very useful to answer the third research questions.

\section{LITERATURE REVIEW}

Historically evidenced that the study of (mass) communication cannot be separated from political practices within a country or community in the respected time. The study of propaganda, political campaign, and advertising are some examples of how close the relationship between media studies and political practices is. According to Soroka (2003) "policy makers follow media reports on public opinion, and the media are the public's chief source of information on what policy makers are doing". He then explains that media is the main tool by which the majority of individuals receive information about the policy, an issue for which personal experience is unlikely to provide much useful information.

This is also implied in the Lasswell's definition about political practices (In Nimmo, 1978). He defines political practices as who gets what, when and how. "Who" is the politician or the policy maker. He/she can use media to do political campaign or to introduce such program / political decision to public. Through framing and or priming strategy media can create the salience of the program/the decision (the when and the how) in order to get political vote (the what).

The role of media/journalists in the political communication process could be as transmitter, constructer, and influencer as well (McNair, 1995: 215). From the perspective political actor, mass media is, since its coverage is almost unlimited, a good tool to introduce a political program, then disseminate it to gain political support from public (transmitter function). On the other hand, from the perspective journalism, media has the opportunity and power to create political context, images about the respective actor in such a way (framing technique) to affect and direct public opinion as they wish (constructer function). Once again, through framing strategy media/journalists can promote a candidate (political actor) to raise his/her popularity, to improve his/her social status, and to create better image so that he/she can win the vote (influencer function).

However, the role and the function of media might only operate healthy within a democratic country or society which applies freedom of the press. Freedom of the press is "the right of newspapers, magazines, etc., to report news without being controlled by the government” (Mirriam-Webster Dictionary).

The study of media effect can follow two different approaches (micro and macro levels). Though they have overlap to each other in practice (Leiserowitz, 2004), the approach have different concern and unit analysis. So differentiate them is a good practice to 
analyze in more precise the impact of media on public, how it happens, in what way, and under what circumstances.

In the micro level the unit analysis of media study is typically the individual media user, and the focus is on the relatively narrow question of whether exposure to a particular media message impacted that user's attitudes, beliefs, cognitions, or behaviors. When we talk about media impact, on the other hand, the orientation can be characterized as a bit more macro, in that the concerns extend beyond whether individual media users had their attitudes, beliefs, cognitions, or behaviors affected, to also include broader systemic changes at the levels of organizations and institutions (Inagaki, 2007)

\section{Meassuring Media Effect}

Chaffee (In Day, 2000) suggests a strategy to identify the possible effect of media, and media indicators effectiveness as follows:

- Different media has different effect. So. It is better to separate the effect that embeds in the media characteristic.

- Grouping the effect according to its categories: cognitive (: understanding, acceptance etc.); behavioral (: changing in feeling, attitude, opinion, etc.); and affective (: willingness to act).

- Determine the focus of observation unit: think the possibility of effect occurrence. Remember that the effect does not happen to everyone; the effect might be occurred when someone has discussed with other people (indirect effect or mediated effect); or the effect is as a result of his/her position/status in a larger certain social system.

\section{Freedom of the press}

In order to be able to play their role, as above described, journalists (media) should hold "freedom of the press". This is a prescription. Journalists should feel free without feeling under pressured. The importance of freedom of the press, according to Zelezny (In Samuels, 2001) is based on two reasons i.e: social reason and individualistic reason:

Social reason: this reason includes:
- Seeking for truth: Freedom of the press is not a destination. Freedom of the press is a tool or vehicle to seek or reach the truth.

- Participation in the process of democracy: as suggested by Alexander Meiklejohn that (In Samuels, 2001) in the United States of America, freedom of speech is protected not only as a vehicle to reach/seek the truth, but also as a medium for sharing the truth. The main objective is to ensure that every voter has the same opportunity to get involved in understanding and seeking for solution to any governmental and societal problems.

- The need to control government policies: through freedom of the press people or media can control to the government from abusing power.

- Social and political stability: It is assumed freedom of the press is able to guard social and political stabilities. Freedom of the press can create information flows making people possible to realize and understand about societal and political problems in better way and perspective so that they will be more rational in dealing the problems.

Individualistic Reason: Freedom of the press is an individual right. It is not questionable right. Freedom of the press is one of human right. Therefore, government has no right to forbidden it.

On the basis of above explanation, it can be concluded that: freedom of speech, expressing ideas either in the form of written or oral, which are the spirit of freedom of the press, are valuable to be reached. Freedom of the press contains universal values. However, each country tends to apply different criteria and spirit. This issue should be understood carefully and proportionally.

There are general principles about freedom of the press, but there is no concept of freedom of the press that can be applied generally. Each community or country tends to develop its own freedom of the press according to its own concept on the basis of its own social and cultural background.

Moral or ethical code of conduct is factors that differentiate the color of freedom of the press from 
country to country. Morale or ethic is cultural product of respective society. So, moral and ethics will explain why contain and coverage of freedom of the press differs from country to country. This implies the idea and function of freedom of the press to create better social life could be universal, but every society has the authority to define its content, direction and coverage of freedom of the press according to social and political norms applying in the respective state or society.

Freedom is an important tool to seek truth and justice. Through freedom of speech, we can compromise any differences. Morale or ethic, in this case, plays an important role to reach a compromise among difference ideas, opinion etc. This means there is no absolute freedom of the press. The execution of freedom the press should consider other human right.

Truth, honesty, and justice are some valuable parameters to develop freedom of the press. Truth is identic to fact. News or journalism should be constructed on the basis of fact. News should be factual and supported by accurate data. Therefore, truth is a fundamental value for freedom of the press practices.

The value of truth in journalism practices is at least based on three reasons (Day, 2000: 79-80): First: decreasing journalists' integrity. It seems journalists are getting more interested in increasing his/her popularity instantly. In this situation, they are more interested in increasing news value by sacrificing their social responsibility.

The second reason is that journalists' commitment to the truth is a form of honor to the existence of other people. It is not good idea to treat other people or news resources as a news object. And the third: "truth" is an essential factor for democracy processes.

Honesty is the next parameter for journalistic practices. "Honesty" has more complicated meaning is factual, but factual does not always mean honest. Framing strategy applied by journalist is a good example of the difference between truth and honest.

The third parameter is justice. According to Christians (In Day, 2000) justice is a relationship between communication, democracy and human right. Justice is an effort to serve what should be provided to other people. Justice emphasizes on providing human basic needs, either as an individual or as part of a group. Journalism or media holds social responsibility i.e developing political commitment to change the public to be more structured society and to be more participative in democratic processes, according to human basic needs individually, socially, and culturally.

This parameter also underline that freedom of the press is not just informing the fact and displaying data. Moreover, freedom of the press should maintain good relationship so that the press is able to enlighten to the public.

\section{Contain Analysis}

"Content analysis is any research technique for making inferences by systematically and objectively identifying specified characteristics within text" (Stone, Dunphy, Smith \& Ogilvie, 1996: in Herrera, 2004). Similar definition is also stated by Weber (1990). He states "content is a research method that uses a set of procedures to make valid inferences from text" (In Hardy, 2004).

More practically Neuman (1997) defines content analysis as a technique for gathering and analyzing the content of text. The 'content' refers to words, meanings, pictures, symbols, ideas, themes, or any message that can be communicated. The 'text' is anything written, visual, or spoken that serves as a medium for communication" ( In Krippendorff, 2013). Content analysis “... is a research technique that is based on measuring the amount of something (violence, negative portrayals of women, or whatever) in a representative sampling of some massmediated popular form of art" (Berger, 1991: in Krippendorff, 2013).

Content analysis will be used to count the occurrence of particular words, news sources, broadcasting frequency, key person invited in the news. This is to evaluate how objective the media/journalist is. To do this, the author will use formula developed by Marras (2013) which consists of values, process, and language. This three key aspects will be taken together to address the essential idea of journalistic objectivity. This formula is operationalized by Dennis (In Sonnemaker, 2015), as follows:

- Separating facts from opinion.

- Presenting an emotionally detached view of the news.

- Striving for fairness and balance 
- This formula will be combined with Chaffee's strategy to identify the possible effect of media, and media indicators effectiveness, as described above.

\section{Agenda-Setting Theories}

Agenda setting describes a very powerful influence of the media - the ability to tell us what issues are important. As far back as 1922, the newspaper columnist Walter Lippman was concerned that the media had the power to present images to the public. McCombs and Shaw investigated presidential campaigns in 1968, 1972 and 1976. In the research done in 1968 they focused on two elements: awareness and information. Investigating the agendasetting function of the mass media, they attempted to assess the relationship between what voters in one community said were important issues and the actual content of the media messages used during the campaign. McCombs and Shaw concluded that the mass media exerted a significant influence on what voters considered to be the major issues of the campaign.

Agenda-setting is the creation of public awareness and concern of salient issues by the news media. Two basis assumptions underlie most research on agendasetting: (1) the press and the media do not reflect reality; they filter and shape it; (2) media concentration on a few issues and subjects leads the public to perceive those issues as more important than other issues. One of the most critical aspects in the concept of an agenda-setting role of mass communication is the time frame for this phenomenon. In addition, different media have different agenda-setting potential. Agenda-setting theory seems quite appropriate to help us understand the pervasive role of the media (for example on political communication systems).

Bernard Cohen (1963) stated: "The press may not be successful much of the time in telling people what to think, but it is stunningly successful in telling its readers what to think about."

Following in large part from Cohen's thesis, empirical agenda-setting research has demonstrated powerful links between media content and public concern across a wide variety of issues. 2 Agendasetting analysis and foreign policy research have only intermittently crossed paths, however. Public agendasetting scholars have given limited attention to foreign policy (e.g.,Gonzenbach 1992; Huegel et al.1989; Iyengar and Simon 1993; Wanta and $\mathrm{Hu}$ 1993).The foreign policy literature, however, has steered clear of the open-ended public opinion measure central to agenda-setting analysis: "What do you think is the most important problem facing our country today?"

\section{Framing theory}

Framing is a mean to achieve it and can be described as "the selection of elements within a particular issue." (McCombs et al., 2013: 8). "Framing is a critical activity in the construction of social reality because it helps shape the perspectives through which people see the world" (Hallahan, 1999: 207).

The Dutch communication scholar de Vreese's view on frames includes sociological work by Goffman and his description of a frame as being "an arbitrary slice or cut from the stream of ongoing activity" (Goffman, in de Vreese, 2005: 22). It suggests that a frame does not tell the whole story but chooses to show only some of it. Frames are "“interpretive packages' that give meaning to an issue" (Gamson and Modigliani, in de Vreese, 2005: 26). Framing can then be built on this to put "an emphasis in salience of some aspects of a topic." (de Vreese, 2005: 27).

It is important to notice that framing is not about arguing and "strong frames should not be confused with intellectually or morally superior arguments." (Chong and Druckman, 2007: 111). Arguments strive to convince another partaker in a discussion by using for example facts. Use of framing in a discussion may already have achieved its objective by causing the discussion in the first place which looks at one perspective of an issue which can avoid or prevent discussing another perspective of it.

According to Entman who is a widely cited communication scholar in framing literature, framing is about making certain aspects of an issue more salient in communication than others (Entman, 1993: 52). Chong and Druckman define it as a process of shaping connotations. It can involve both how people start to think about an issue and how they change their thinking about an issue (Chong and Druckman, 2007: 104).

In essence, the use of framing and its results can be summed up using a simple example. A study of a television show clearly showed different effects on 
how it was perceived corresponding to different ways of framing it (McCombs et al., 2013: 17). The same show was broadcasted on several channels each having their own commentators to commentate it. Apart from the commentators, the show was identical on each channel. As the commentators emphasized different elements of the show, the viewers had different thoughts about it afterwards depending on which channel they had been watching. Their perceptions of the event were thereby based on what the commentators highlighted regardless of whether this was intentionally or not. Different ways of framing the same issue resulted in different ways of perceiving it even while having the same information available.

Frames are most often used to promote a certain viewpoint on a topic such as a way of evaluating, defining or understanding it (Entman, 1993: 52). Goffman defined frames from another perspective as a frame explains how we understand the world and are able to "locate, perceive, identify, and label" events when we interpret them (Goffmann, in de Vreese, 2005).

Framing deliberately focus on the communicative elements that evoke responses and rational deductions leaving the receivers to believe that the most logical interpretation was made (Bennett, in Darmon et al., 2008: 374). According to the definitions however, these decisions may only seem logic as long as not all parts of the relevant issue are emphasized.

Simple changes in the wording of a text can change people's attitudes towards the issue at hand. Words can serve as indirect hints about the preferable perspective to take and can have an impact on how much receivers consider the situation and whether they are for or against it (Wang, in de Vreese, 2005: 23; Chong and Druckman, 2007: 104).

Frames draw attention to elements and thereby activate some of the knowledge that individuals already have. This knowledge may be cultural norms, values etc. and by drawing attention to some elements and perhaps away from other elements, it stimulates specific parts of this knowledge and creates a context (de Vreese, 2005: 26).

Besides this, they define problems (In terms of common cultural values), diagnose causes, make moral judgments (Evaluate these causes) and recommend remedies (Offer to solve problems, justifying it and foretell how this will probably work) (Darmon et al., 2008: 374; Entman, 1993: 52). "Framing increase the productivity of interpersonal negotiations, and serve as a foundation for public discourse, such as negotiation, on a masscommunication level.” (Knight, 1999: 383).

\section{The Case of Indonesia}

According to American historian, Paul Johnson (In Anom, 2011), Indonesian journalists conduct "seven deadly sins", as follows:

First: Information distortion; Indonesian journalist tends to add or reduce information to create intended context to increase news value.

Second: Fake fact dramatization; Media/journalists are over action in including verbal and visual illustrations to create dramatic news.

Third: Privacy offensive: Just wants to be the first, media/journalist tends to ignore other person privacy. For example, asking very personal question to politician who is getting involved in a scandal.

Fourth: Character killing: Media/journalists tend to describe, exploit and give more emphasis on bad side of news object, leading to public trial.

Fifth: Sex exploitation; this sin is dealing with the use of woman in advertisement.

Sixth: Poisoning child mind; this sin is mainly related to the use of children in advertisement.

Seventh: Abuse of the power; Some media editors use their authority to ask journalists to use hidden-camera or recorder to get very sensitive information.

\section{FINDING AND DISCUSSION}

\section{Content analysis}

It is believed that media want to blow up the issues of Setyo Novanto and Basuki Tjahaja Purnama. Within two months period (November-December 2015), the issue was broadcasted 79 times. This is not included news broadcasted by other television stations. The following is the complete content analysis result for those issues. 
Table 1: Frequency Distribution Of Setyo Novanto Dispute

\begin{tabular}{|l|l|l|l|l|l|}
\hline \multirow{2}{*}{$\begin{array}{l}\text { Time } \\
\text { Period }\end{array}$} & \multicolumn{2}{|l|}{ T One } & \multicolumn{2}{l|}{ Metro TV } & \multirow{2}{*}{ Total } \\
\cline { 2 - 5 } & News & Others & News & Others & \\
\hline November & 14 & 6 & 20 & 5 & 45 \\
\hline December & 13 & 5 & 12 & 4 & 34 \\
\hline Total & 27 & 11 & 32 & 9 & 79 \\
\hline
\end{tabular}

Content analysis result, January, 2016

The above table tells us how often the media broadcast the issue of Freeport gratification in which Mr. Setyo Novanto is getting involved in it. The data shows that the two media have almost the same attention about the importunateness of the issue.

The author believe that the media have intended purpose for taking such redundancy in broadcasting the issue. Since there are some other national issues that are considered more relevant in terms of overcoming problems faced by Indonesian government. It is reasonable if the media/journalists were blowing up the issue.

The same policy seems also to be applied in the second issue. Table 2 presents the detail of the data.

Table 2:Frequency Distribution Of Basuki Tjahaja Purnama (Btp) Disputes

\begin{tabular}{|l|l|l|l|l|l|}
\hline \multirow{2}{*}{$\begin{array}{l}\text { Time } \\
\text { Period }\end{array}$} & \multicolumn{2}{|l|}{ T One } & \multicolumn{2}{l|}{ Metro TV } & \multirow{2}{*}{ Total } \\
\cline { 2 - 5 } & News & Others & News & Others & \\
\hline November & 21 & 7 & 4 & 2 & 34 \\
\hline December & 13 & 5 & 2 & 2 & 22 \\
\hline Total & 34 & 12 & 6 & 4 & 56 \\
\hline
\end{tabular}

Content analysis result, January, 2016

As can be seen from the table 2, TvOne is more interested in reporting the issue of Basuki Tjahaja Purnama(BTP) compared to MetroTV. This is not surprising since the television stations have different political affiliation, and one of them has the same political affiliation as BTP does. TvOne belongs to Bakrie group (has political affiliationto Golkar) whereas MetroTv belongs to Media group (has political affiliation to Nasional Demokrat).

This is confirmed to the statement of Owen and Wildman (1992) that "media firms have a room to produce more specialized program for capturing niche market by making use of their financial resources, based on profit maximization strategy". According to McChesney (2000, as cited in Barnet, 2010) "the wealthier and more powerful the corporate media giants have become, the poorer the prospect for participatory democracy". Moreover, "a healthy democracy depends on a culture of dissent and argument, which would inevitably be diminished if there were only a limited number of providers of news" (Barnett, 2010, as cited from DCMS, 2001: 7).

The above argument is also confirmed by editorial policy, as resulted from content analysis. Figure-1 presents data/information about "framing process of news production", summarized from in depth interview with some experts and journalist representing the two media. The media seems to apply almost the same strategy and process. The different is laying in the degree of capital owner influences the editorial policy and morale understanding among journalist.

The figure shows, as starting point, media/journalist can pick issue discussed in social media and/or public events, as news object. It is journalist or editor responsibility to frame the object to become a news ready to be broadcasted. It really depends on journalists' morale, which issue the journalist want to broadcast and in what way. The journalists then consult to political interest to whom the capital owner affiliated to.

In the case of Setyo Novanto, it seems there is a special arrangement. Journalist starts from rumor discussed in social media. The "as said" journalism is applied to attract comment from politicians who do not agree with or have ambition to replace Mr. Setyo Novanto as the leader of Indonesian Parliement. Through redundancy and live discussion inviting selected politicians, media/journalist is successfully raising Mr. Setyo Novanto dispute to be the most urgent national issue at the respective time. The end of the attraction is Mr. Setyo Novanto resigns from his position as the Indonesian Parliament Leader and he is accused guilty in the case of "Freeport gratification" without hearing in the court. 

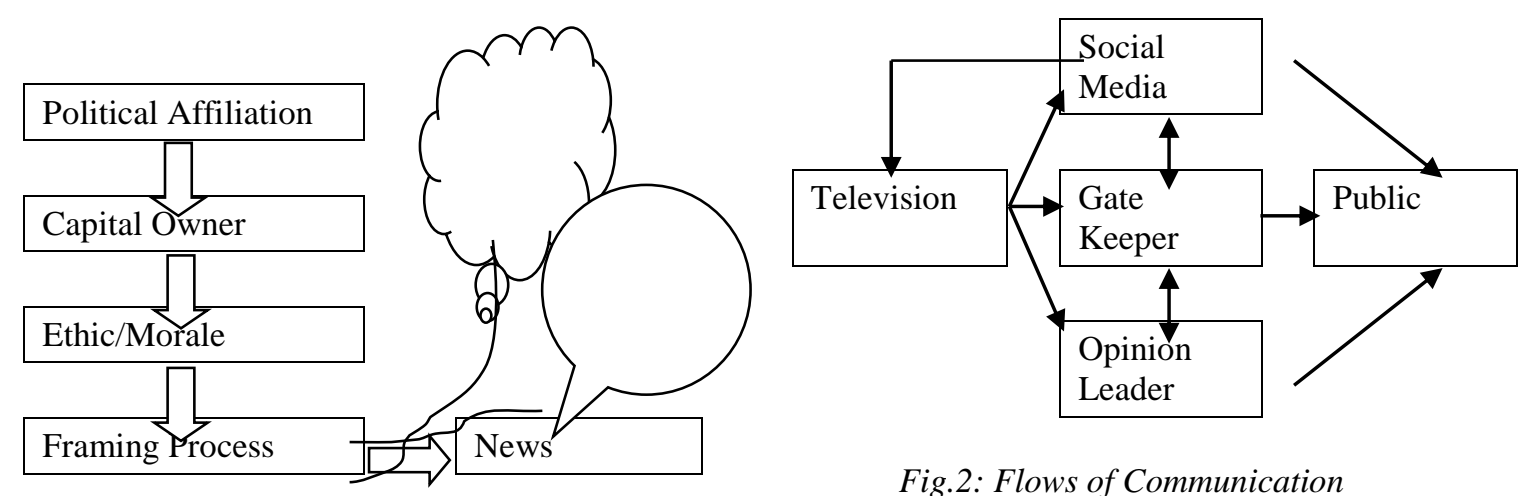

Fig.2: Flows of Communication

Fig. 1: framing process of news production

In the contrary, BTP gets benefit from the news broadcasting. He is getting more popular leading to the raise of his electability in the next governor election.

In this issue, media/journalist begins with issue spreading in public. BTP is known as controversial governor. His action and statement are always attracting public debate. The content analysis result shows that media/journalist tries to blow up the issue by inviting politicians, government officials, academicians, and religion leaders, in live talk show. Most of the invited persons are politically against BTP.

This study does not have enough data/information about the exact purpose of why the media/journalist does such thing. However, it can be seen from content analysis result that media/journalist want to saturate BTP's character as the Governor of Jakarta. This is based on the news content which is mostly about negative manner of BTP. Even though based on limited data, this finding confirms to Johnson's conclusion ie. "character killing".

Journalist also invites political opponent as the news sources. This is another evidence that media/journalist develops a specific arrangement about BTP. What happens in the field is in the contrary. This is an interesting finding, and a good example as well, that what happens to BTP is beyond media/journalist expectation. BTP is getting more popular as a result of the broadcasting. His electability as the next Jakarta governor candidate raises significantly.

This study also reveals the general pattern of communication flows in Indonesia. Fig. 2 shows the communication pattern.
It seems Indonesian public follows mediated communication flow in which message is transmitted by mass media, through gate keepers' selection and/or opinion leaders' interpretation, the message then goes to public. So, it is possible that there is a distortion meaning of the actual message. What is understood by public, could not be as an intended purpose of the media/journalist. This might be the answer of BTP issue why the impact of the media is out of its expectation. This reality should be understood carefully.

The communication flow should be considered in explaining the impact media on public. This is confirmed by McCombs's study (2013) about agenda-setting effect. In some cases, agenda-setting effect occurs indirectly. Message comes from media, then, interpreted by gate-keeper or opinion leaders, and finally reaches the public.

In the case of Setyo Novanto, there is a possibility of amplification of the news by gate-keepers or opinion leaders so that magnify the agenda-setting effect. It is reasonable, therefore, if Mr. Novanto is successfully forced to step down from his position as the Indonesian Parliament Chief, and accused guilty without getting proper trial in the court.

\section{Framing analysis}

The following figure is (Fig.2) showing the construction of media-agenda through framing process. 


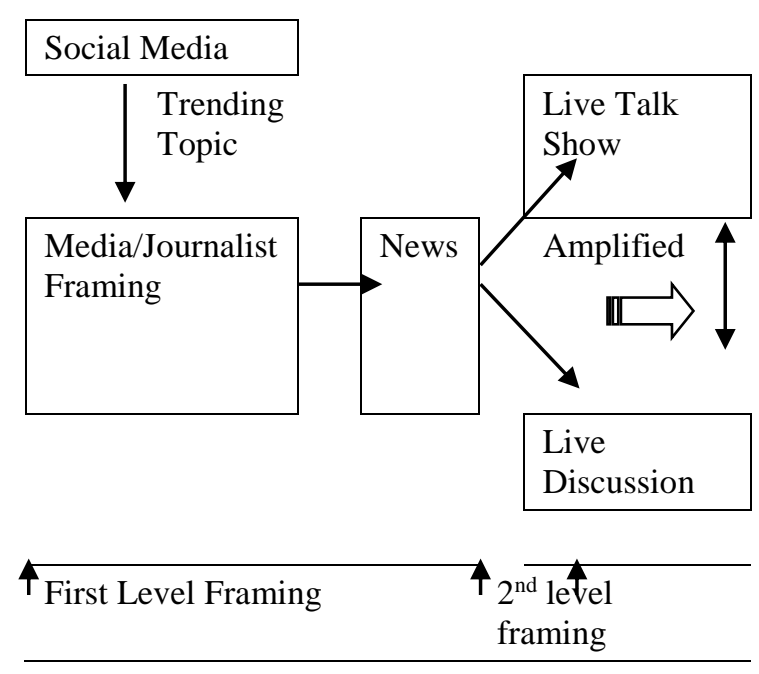

Fig. 3: Media Agenda Process

The figure shows that there are two level of framing processes. In the first level, media/journalist takes the most discussed topic in social media, as "trending topic". The topic is broadcasted repeatedly to attract public attention. The topic is then brought to live talk show inviting selected key persons or to live discussion among selected keynote speakers.

The framing analysis reveals the two media try to compete to each other to be the one or to be the first. When the media comes to decision to create public opinion (agenda-setting effect), an issue is broadcasted by inviting some selected source to get involved in live discussion in the studio or remotely. The resources are often opposing to each other. The journalist quite often takes benefit from the situation to provoke emotion of the sources to get controversial argument/statement leading to the emergence of national discourse. The author believe this is the media strategy to challenge other people involvement in the discourse.

This is the first level of framing as presented the Figure 3. In this level accuracy, balance, and objectivity seem to be ignored. Journalist look more focus on the creation of discourse instead of placing an issue in the right place. This is the way the media frame an issue, at least, according to this study.

The issue is then brought in a talk show or a more systematic discussion program lively, inviting key persons having competence in respect to the issue, to strengthen its impact on public opinion. The framing analysis detects that the journalist applies certain criteria to select the key persons invited in the live talk show or discussion program. This can be seen from the invited persons who have controversial manner.

Since the talk show or discussion program involves key persons coming from different interest and political affiliation, the discussion develops to become cross argument that triggers uncontrolled personal debate. Instead of having clear statement about an issue, the show is used as a media to express his/her political interest. The journalist, on the other hand, takes benefit from the discussion situation to raise the value of the issue to be national discourse.

$\uparrow$

The live talk show or discussion is some time used to create special meaning about an issue. To do this, journalist frequently interrupts the discussion in improper point.

The journalist has the power to control the discussion by asking a series of well-prepared questions in which the invited person is emotionally engaged to provide information as the journalist's wish. This is the second level of framing which is identified in this study. In his/her effort to create special meaning.

There is also tendency to separate context from the fact. This is very dangerous decision. Since every event, issue, and fact has its own context, so separating it from its context will change its meaning and value.

The last, but not least, this study is also identified some phrases/words which are frequently used by the journalist just to cover his/her particular intention. Journalist/media is quite often covering his/her intention by saying "on behalf of justice", "on behalf of public need/want" and many others.

Taking consideration of Indonesian journalism history which is colorized by propaganda (: "hate journalism"), the findings are not surprising. The finding provides evidence that "hate journalism" is still exist in Indonesia, but it appears in more sophisticated form.

\section{CONCLUSION}

On the basis of the above finding and discussion, this study concludes some points as follows:

Indonesian media/journalist tends to treat freedom of the press as an objective instead of a vehicle. This is not just a simple choice. But, it has a great impact on morale and morality of journalist. Freedom of the press is actually a good vehicle to seek justice, to 
develop trust and honesty. Journalist can facilitate public through media to get involved in open debate or discussion, for example, to seek justice, to develop trust, or to be honest to each other. This cannot be reached if the journalist treat freedom of the press as an objective. In this choice journalist tend to use freedom of the press to justify his/her action.

Indonesian journalists tends to ignore social responsibility which is one of the important condition in implementing freedom of the press. This is as a result of treating freedom of the press as an objective. Indonesian journalist is more interesting in pursuing news value and ignoring its impact. It seems, his/her main purposes is how to raise the rating of the news program. Journalist does not care to the impacted public.

Since "hate journalism (propaganda)" is always coloring Indonesian media from time to time, social responsibility should be re-actualized in order to raise the benefit of freedom of the press in the economic, social, and political development in Indonesia.

It is very difficult to weigh the implementation of freedom of the press in Indonesia. Since this study is based only on two issues. However, there is a tendency that freedom of the press practices in Indonesia is beyond expectation. Media which is expected to create social, economy, and political stability tends to grow as a news industry and ignore its main function as public and government enlightenment. If the tendency is not managed properly, it is more likely the freedom of the press practices will produce boomerang effect. It is not impossible the government will take control to the implementation of freedom of the press in Indonesia, meaning goes back to Soeharto era. This will be nightmare for Indonesian journalist.

The finding implies that journalists' morale could be the main problem. Therefore, education intervention is needed to prepare new journalists having highly morale and integrity.

\section{REFERENCES}

Anom, Erman; 2011. Wajah pers Indonesia 1999 - 2011; Jurnal Komunikasi, Malaysian Journal of Communication; Jilid 27 (1): $101-114$

Arifin, Anwar; 1990; Perkembangan pers dan bahasa Melalyudi Indonesia; disampaikan dalam ceramah Jabatan Komunikasi Fakulti Sains Kemasyarakatan dan Kemanusiaan Universiti Kebangsaan Malaysia.
Barnett, Steven; 2010. What's wrng with media monopolies? A lesson from history and a new approach to media ownership policy; Media@1se: Department of edia and Communication, working paper No. 18

Chaffee, Steven H.; Mass media Effect: New research perspectives; In: Mass Communication Review Year Book; Vol 1; Edited by G. Cleveland Wilhoit; Sage Publication, USA 1980

Cohen, Bernard C.; 1963. The Press and Foreign Policy. Princeton, NJ: Princeton University Press.

Chong, Dennis and Druckman, James N. (2007). Framing Theory. Annual Review of Political Science 2007. 10, 10326

Connect!on: Med!aLit Moments; 2016; Consortion for media literacy; Volume No. 79, February 2016.

Darmon, Keren; Fitzpatrick, Kathy and Bronstein, Carolyn (2008). Krafting the obesity message: A case study in framing and issues management. Public Relations Review, 34(4), 373-379

Day, Louis Alvin; 2000; Ethics in Media Communication, Focal Press: London, British de Vreese, Claes H. (2005). Framing Europe: Television news and European integration 2nd ed. Amsterdam: Het Spinhuis

Entman, Robert M. (1993). Framing: Toward Clarification of a Fragmented paradigm. Journal of Communication 43(4), 51-58

Gonzenbach, William J.; 1992. "The World of U.S. Network Television News: Eighteen Years of International and Foreign News Coverage". Gazette 50:53-72

Hallahan, Kirk (1999). Seven Models of Framing: Implications for Public Relations. Journal of Public Relations Research 11(3), 205-242. Published online: 19 November 2009. UK: Routledge

Hardy, Cynthia; Bill Harley; Nelson Phillips; 2004; Discourse Analysis and Content Analysis: Two sillitudes?; In Symposium: Discourse and Content Analysis, Edited by Yoshiko M. Herrera and Bear F. Braumoeller; Qualitative methods, Spring 2004

Hasan, Amirul; 2014; Agama, media dan kekuasaan: analisis is agama dalam pilpres Ri 2014; Jurnal Penelitian KeIslaman, Vol. 10, No. 2, Juli 2014

Herrera, Yoshiko M.; Bear F Braumoeller; 2004; Symposium: Discourse and Content Analysis; Qualitative Methods, Spring; Sage Publication London.

Huegel, R., W. Degenhardt, and H.Weiss.; 1989. "Structural Equation Models for the Analysis of the Agenda-Setting Process". European Journal of Communication 4:191-210

Inagaki, J. (2007). Communicating the impact of communication for development: Recent trends in empirical research. Washington, DC: World Bank.

Iyengar, Shanto, and Adam Simon; 1993. "News Coverage of the Gulf Crisis and Public Opinion: A Study of AgendaSetting, Priming, and Framing". Communication Research 20:365-83.

Knight, Myra Gregory (1999). Getting Past the Impasse: Framing as a Tool for Public Relations. Public Relations Review, 25(3), 381-398 
Krippendorf, Klaus; 2013. Content analysis: an introduction to its methodology Third edition, Sage publication Inc.

Leiserowitz, A.A. (2004). Before and after The Day After Tomorrow: A U.S. study of climate change risk perception. Environment, 46, 22-37

Maras, Steven. Objectivity in Journalism. Cambridge, U.K.: Polity, 2013. Print

McCombs, Maxwell E., Shaw, Donald L. and Weaver, David H. (2013). Communication and Democracy: Exploring the Intellectual Frontiers in Agenda-Setting Theory. Lawrence Erlbaum Associates, Inc

McCombs, Maxwell (2014). Setting the Agenda: The mass media and public opinion. 2nd ed. Polity Press

McNair, Brian; Introduction to political communication; London, Routledge, 1995.

Mirriam-Webster Dictionary Online.

Napoli, Philip.; 2014; Measuring media impact: An overview on the field; School of Communication \& Information Rutgers University Winter 2014

Nimmo, Dan; Political communication and public opinion in America; Santa Monica California: Goodyear Publishing, 1978.

Owen, B. M., \& Wildman, S. S. (1992). Video Economics. Cambridege, MA: Harvard University Press
Samuels, Annette J.; 2001; More than Optional Rules for Right Behavior; The Journal of the Association of Schools of Journalism and Mass Communication, Fall 2001, pp. 24 $-26$

Schillemans, Thomas and Jacobs, Sandra (2014). Between a rock and a hard place: Framing public organisations in the news. In: Pallas, Josef; Strannegård, Lars and Jonsson, Stefan (2014) Organisations and the Media: Organizing in a mediatized world (pp. 148-161). UK: Routledge

Sonnemaker, Tyler; 2015. Objectivity and the Role of Journalism in Democratic Societies; Senior Thesis, Cleremont McKenna College, Fall 2014.

Soroka, Stuart N.; 2003; Media public opinion and foreign policy; Press/Politics, 8 (1) Winter 2003.

Suwirta, Andi; 1999; Zaman pergerakan, pers dan nasionalism di Indonesia; Mimbar Pendidikan No. 4, Bandung: Universitas Pendidikan Indonesia, 1999).

Wanta, Wayne, and Yu Wei Hu; 1993. "The AgendaSetting Effects of International News Coverage: An Examination of Differing News Frames". International Journal of Public Opinion Research 5:250-64.

Weaver, D. H., McCombs, M., \& Shaw, D. L. (2004). Agenda-setting research: Issues, attributes, and influences. In L. L. Kaid (Ed.), Handbook of political communication research (pp. 257-282). Mahwah, NJ: Lawrence Erlbaum 